\title{
LEARNING MODEL BASED ON PANDE TRADITIONAL GAME TO STRENGTHEN STUDENT CHARACTERS
}

\section{Yuniatun Dwi Nurriskah, Idzaa Zubdatun Thoyyibah, Muhamad Chamdani}

Universitas Sebelas Maret

yuniatundn@gmail.com

\section{Article History}

accepted 30/09/2018

approved 12/10/2018

published 30/10/2018

\section{Keywords}

Learning model, traditional game, character education

\begin{abstract}
This article aims to create new innovations on learning models so that learning in elementary schools can take place effectively and be able to strengthen student character development. The research method used is literature study. Data collection is carried out with studies of books, literature, records, and reports relating to the problem being solved. Literature sources in this study were obtained from books, journals, and research results. This research includes the process of systematically identifying the theory, finding literature, and analyzing documents that contain information related to the research topic. The results of this study are in the form of learning models that can be applied by the teacher to achieve the learning objectives effectively and strengthen student character development.
\end{abstract}

Social, Humanities, and Education Studies (SHEs): Conference Series https://jurnal.uns.ac.id/shes

p-ISSN 2620-9284 e-ISSN 2620-9292 


\section{PENDAHULUAN}

Perkembangan Ilmu Pengetahuan dan Teknologi (IPTEK) yang begitu pesat dalam era globalisasi menimbulkan perubahan tingkah laku yang berbeda pada manusia. Menurut Dahliani (2015) bahwa globalisasi dapat mempengaruhi kearifan lokal melalui pola pikir manusia. Di era modern yang serba canggih ini membuat negara Indonesia nyaris kehilangan segala sesuatu yang bersifat tradisional. Permainan tradisional seperti lompat tali, gobag sodor, ular naga panjang, cak dodok, ancik-ancik alis, pande dan lain sebagainya, kini semakin dilupakan karena permainanpermaian tersebut tergantikan oleh game modern seperti game online dan play station.

Permainan digital seperti video games dan games online, lebih banyak dimainkan secara statis, anak bermain dalam keadaan pasif. Mereka duduk dan diam, yang bekerja hanya jemarinya saja. Hal ini menyebabkan anak menjadi tidak peduli pada lingkungan yang akanmempengaruhi interaksi sosial anak, akibatnya, anak berkembang menjadi pribadi yang pemalu, penyendiri, dan individualistis. Di samping itu, permainan ini juga menciptakan suasana tegang dan menimbulkan agresi yang kuat, yang membentuk anak untuk cenderung ingin menang dan akan sangat kecewa bahkan tidak bisa menerima kekalahan (Nur, 2013). Hal tersebut membuktikan bahwa game online berdampak negatif bagi anak, yaitu membuat karakter anak yang enggan bersosialisasi dengan lingkungan sekitar. Kurangnya interaksi sosial menyebabkan pembinaan karakter pada anak kurang. Masalah ini bisa berlanjut sampai anak itu menjadi dewasa sehingga karakter yang kurang baik akan terus berkembang.

Permainan tradisional merupakan simbolisasi dari pengetahuan yang turun temurun dan mempunyai bermacam-macam fungsi atau pesandibaliknya. Selain itu permainan tradisional adalah hasil budaya yang besar nilainya bagi anak-anak dalam rangka berfantasi, berekreasi, berkreasi, berolah raga yang sekaligus sebagai sarana berlatih untuk hidup bermasyarakat, keterampilan, kesopanan serta ketangkasan, sehingga dapat digunakan untuk pendidikan karakter pada anak (Andriyani, 2012). Pengintegrasian pendidikan nilai (karakter) pada setiap mata pelajaran, menjadi sangat penting demi kesiapan siswa dalam menghadapi setiap permasalahan dalam kehidupannya. Beberapa kasus kriminal yang melibatkan anak usia sekolah menjadi bukti empirik betapa pentingnya penanaman karakter dalam kegiatan belajar mengajar disekolah (Qodriyah, 2015).

Berdasarkan penelitian yang dilakukan Angela (2013) motivasi belajar yang dimiliki anak yang bermain game online cenderung rendah karena anak lebih cenderung memilih kegiatan yang mengasyikan, malas belajar, tidak perduli dengan tugas-tugas sekolahnya sehingga motivasi belajarnya akan menurun dengan sendirinya. Selanjutnya berdasarkan pengamatan awal di SDN 4 Kutosari Kebumen, menunjukkan bahwa permainan tradisional pande jarang dimainkan. Hal ini dapat menunjukkan bahwa permainan pande hampir tidak dikenal. Selain itu, game online hampir dimainkan oleh sebagian besar anak-anak di SD tersebut.

Untuk membentuk karakter positif, kita dapat memanfaatkan kebudayaan yang ada di Indonesia, salah satunya yaitu melalui permainan tradisional pande sebagai model pembelajaran di SD. Model pembelajaran tersebut merupakan solusi yang tepat untuk mengatasi permasalahan karakter yang kian hari semakin melemah. Karena sifat anak SD yang senang bermain, sehingga pembelajaran dengan bermain tepat untuk dilaksanakan.

Berdasarkan latar belakang di atas, akan dibahas beberapa hal diantaranya:

1. Apakah pengertian model pembelajaran?

2. Apakah pengertian permainan tradisional pande?

3. Bagaimana model pembelajaran berbasis permainan tradisional pande?

4. Bagaimana peran model pembelajaran pande terhadap pembentukan karakter siswa? 
Tujuan dilaksanakannya penelitian ini adalah untuk menjelaskan pengertian model pembelajaran, menjelaskan permainan tradisional pande, mendeskripsikan model pembelajaran berbasis permainan tradisional pande, serta menjelaskan peran model pembelajaran pande terhadap pembentukan karakter siswa.

\section{METODE}

Metode yang digunakan dalam penelitian ini yaitu studi kepustakaan, menurut Nazir (2003), mengemukakan bahwa "studi kepustakaan adalah teknik pengumpulan data dengan mengadakan studi penelaahan terhadap buku-buku, literatur-literatur, catatan-catatan, dan laporan-laporan yang ada hubungannya dengan masalah yang dipecahkan." Peneliti melakukan kajian yang berkaitan dengan teori yang berkaitan dengan topik penelitian, mengumpulkan informasi sebanyak-banyaknya dari kepustakaan yang berhubungan.

\section{Model Pembelajaran}

\section{HASIL DAN PEMBAHASAN}

Menurut Joyce dalam Trianto (2009: 22), model pembelajaran adalah suatu perencanaan atau suatu pola yang digunakan sebagai pedoman dalam merencanakan pembelajaran di kelas atau pembelajaran dalam tutorial dan untuk menentukan perangkat-perangkat pembelajaran. Menurut Arends dalam Trianto (2009: 22) menyatakan bahwa model pengajaran mengarah pada suatu pendekatan pembelajaran tertentu termasuk tujuannya, sintaknya, lingkungannya, dan sistem pengolahannya. Dari beberapa pendapat di atas dapat disimpulkan bahwa model pembelajaran adalah suatu rancangan pembelajaran yang di jadikan dasar oleh seorang guru untuk melakukan pembelajaran yang di harapkan dapat mencapai tujuan pembelajaran.

Mengajar adalah membimbing kegiatan pembelajaran siswa, agar siswa terlibat secara aktif dalam kegiatan pembelajaran. John Dewey sebagai tokoh pendidikan, mengemukakan pentingnya prinsip ini melalui metode proyek dengan semboyan learning by doing. Aktivitas belajar murid yang dimaksud di sini adalah aktivitas jasmaniah maupun aktivitas moral. (Raharjo, 2012: 1-2)

Terdapat beberapa konsep untuk menjelaskan model pembelajaran yang dikemukakan oleh Rusman (2012: 136), yaitu (a) syntax, urutan langkah-langkah pembelajaran; (b) principle of reaction, yaitu bagaimana guru dapat memandang, merespon siswa dan memperlakukan siswa; (c) social system, yaitu menggambarkan peran dan hubungan siswa dengan guru, serta berbagai norma yang digunakan pada saat pembelajaran; (d) support system, menggambarkan sarana atau media yang dapat mendukug pembelajaran. Dan memiliki dampak sebagai akibat terapan model pembelajaran. Dampak tersebut meliputi: (1) Dampak pembelajaran, yaitu hasil belajar yang dapat diukur; (2) Dampak pengiring, yaitu hasil belajar jangka panjang.

\section{Permainan Tradisional Pande}

Permainan tradisional Pande atau Engklek adalah sebuah permainan tradisional yang dilakukan dengan melemparkan sebuah pecahan genteng ke dalam lapangan pande. Pada masa kolonial Belanda, permainan ini bernama zondaag mandaag yang kemudian dimainkan oleh anak-anak pribumi sehingga semakin luas dimainkan di Indonesia.

Jenis permainan ini berhubungan dengan melompati petak-petak yang digambar di lantai atau tanah. Satu anak hanya membawa satu potongan genteng atau yang sering disebut kunci. Lapangan pande tersebut memiliki bermacam-macam bentuk, seperti bentuk ketupat/kincir, almari, masjid, petak, dan sebagainya. Lapangan pande yang digunakan dalam model ini yaitu lapangan pande kincir. 


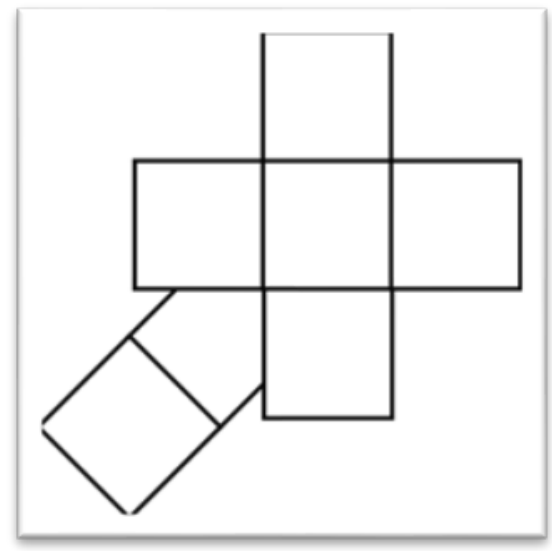

\section{Gambar 1. Bentuk lapangan Pande Kincir}

Pemain pande harus melompat ke setiap petak sampai petak terakhir lalu kembali lagi. Saat pemain sampai di tempat kunci miliknya, pemain harus mengambil kunci tersebut dengan tangan sementara kakinya tidak boleh menyentuh garis. Jika pemain melanggar aturan maka pemain tidak boleh melanjutkan permainan pande sampai dapat gilirannya kembali. Permainan selesai jika kunci pemain berhasil melalui semua petak dan dapat kembali ke petak pertama dengan selamat.

\section{Model Pembelajaran Berbasis Permainan Tradisional Pande}

Model pembelajaran berbasis permainan tradisional pande adalah model pembelajaran yang memadukan konsep permainan tradisional pande dengan materi pembelajaran. Pengintegrasian ini dilakukan dengan mengembangkan permainan sehingga sesuai dengan bagian-bagian model pembelajaran yaitu urutan langkahlangkah pembelajaran (sintak), sistem sosial, prinsip reaksi, sistem pendukung, dampak intruksional. (Rusman, 2012).

1. Sintak

Sintak model pembelajaran berbasis permainan ini yaitu:

A. Tahap Pra Pemainan

1. Penataan situasi untuk mempersiapkan siswa mengikuti pembelajaran.

2. Penyampaian tema, tujuan, dan langkah-langkah pembelajaran.

3. Penggalian kemampuan awal siswa oleh guru dengan pretes. Pretes adalah jenis tes kemampuan awal siswa yang dilakukan sebelum siswa mempelajari suatu pokok bahasan (Suwandi, 2011). Hal ini ditujukan untuk menentukan 4 siswa dengan kemampuan awal terbaik agar menjadi pengawas permainan.

4. Guru membagi sejumlah siswa menjadi 4 kelompok (selain 4 siswa terbaik) dan menugaskan untuk membuat lapangan pande masing-masing kelompok.

5. Memberikan tugas pengawas kelompok yaitu: membacakan soal yang diberikan di setiap kartu petak 1-8; tidak membocorkan soal maupun jawaban kepada temannya; menjadi timer dengan maksimal 30 detik jawaban teman sekelompoknya; menghitung skor yang bisa dijawab masing-masing temannya.

6. Pengawas mengawasi masing-masing satu kelompok.

B. Tahap permainan

1. Siswa yang mendapat giliran melemparkan kunci ke petak 1, jika siswa kunci bisa masuk ke petak 1, maka pengawas akan membacakan pertanyaan. Pertanyaan harus segera dijawab dalam waktu maksimal 30 detik. 
2. Jika jawaban benar, maka siswa bermain dengan melompat hingga mengambil kunci serta kembali ke posisi awal.

3. Siswa kembali melemparkan kunci ke petak 2, lalu pengawas akan membacakan pertanyaan kedua.

4. Siswa dinyatakan kalah apabila: tidak bisa menjawab pertanyaan; menjawab lebih dari 30 detik; dan menginjak garis pada lapangan pande.

5. Permainan dilakukan bergantian dengan anggota kelompok yang lain.

6. Siswa yang sudah bermain berdiskusi dan menuliskan ringkasan singkat dari materi yang dibahas.

7. Presentasi kelompok tentang materi yang dibahas serta hal yang dapat dipelajari dari permainan pande.

C. Tahap penutup

1. Pemberian penghargaan kepada kelompok yang menang.

2. Penarikan kesimpulan dari pembelajaran yang telah dilakukan

3. Pemberian evaluasi terhadap pembelajaran

4. Pemberian tindak lanjut

5. Penutup pembelajaran

2. Sistem sosial

Sistem sosial yang terjadi pada model dibangun berdasarkan interaksi antara siswa dan siswa serta antara guru dan siswa. Siswa bersama-sama membangun pengetahuannya secara individu dan juga berdiskusi dengan kelompok. Guru berperan sebagai fasilitator, pengatur, sekaligus pengawas dalam pembelajaran dan saat permainan berlangsung.

3. Prinsip reaksi

Guru diarahkan sebagai pembimbing siswa dalam penemuan konsep dalam diri siswa dan dapat merespon tingkah laku dan pemikiran/konsep siswa dengan tepat. Guru diletakkan sebagai aktor yang berperan mampu memverifikasi kegiatan pembelajaran berupa penguatan pengetahuan, refleksi kegiatan pembelajaran, pemberian pesan moral yang sesuai dengan tujuan pembelajaran.

4. Sistem pendukung

Sistem pendukung dalam model pembelajaran permainan pande berupa lapangan/halaman, sumber belajar, dan lembar pertanyaan. Sumber belajar berupa buku dan lingkungan sekitar.

5. Dampak intruksional

Dampak langsung yang dihasilkan yaitu siswa dapat mencapai tujuan pembelajaran yang maksimal karena siswa belajar dengan cara yang menyenangkan. Dampak pengiringnya yaitu mampu menggali karakter positif yang dimiliki siswa.

\section{Peran Model Pembelajaran Pande Terhadap Pembentukan Karakter Siswa}

Karakter adalah nilai-nilai yang khas berupa watak atau kepribadian seseorang yang terbentuk dari hasil internalisasi berbagai kebiasaan cara pandang, berpikir, bersikap, berucap, dan bertingkah laku sehari-hari. Hermawan Kertajaya dalam Asmani, J.M. (2013) mengemukakan bahwa karakter adalah ciri khas yang dimiliki individu atau benda yang mengakar pada kepribadian individu tersebut serta mendorong bagaimana seseorang bersikap, bertindak, berucap, dan merespon sesuatu.

Menurut Kemendiknas Badan Penelitian dan Pengembangan Kurikulum (2011) untuk lebih memperkuat pelaksanaan pendidikan karakter pada satuan pendidikan telah teridentifikasi 18 nilai yang bersumber dari agama, Pancasila, budaya, dan tujuan pendidikan nasional, yaitu: religius, jujur, toleransi, disiplin, kerja keras, kreatif, mandiri, demokratis, rasa ingintahu, semangat kebangsaan, cinta tanah air, menghargai prestasi, bersahabat/ komunikatif, cinta damai, gemar membaca, peduli lingkungan, peduli sosial, tanggung jawab. Pendidikan melalui aspek pembelajarannya 
diharapkan mampu memberikan kontribusi yang positif terhadap pembentukan karakter siswa. Model pembelajaran berbasis permainan tradisional pande mampu menghadirkan pembelajaran yang dapat memperkuat karakter siswa.

Pada tahap pra permainan diperkuat karakter spiritual dari kegiatan berdoa, karakter rasa ingin tahu dari menggali kemampuan siswa, karakter bersahabat/komunikatif melalui kerja kelompok, karakter menghargai prestasi dari memberi selamat kepada teman yang nilai pretesnya terbaik, serta karakter bertanggungjawab dari siswa terpilih yang melaksanakan tugas khususnya.

Pada tahap permainan diperkuat karakter kerja keras dari menyelesaikan permainan serta menjawab pertanyaan, karakter disiplin dari tertib mengikuti aturan permainan, karakter komunikatif melalui diskusi serta mengungkapkan jawaban pertanyaan kelompok dan mempresentasikannya.

Pada tahap penutup diperkuat karakter menghargai prestasi melalui memberi selamat kepada kelompok yang menang, karakter mandiri dari menyimpulkan pembelajaran secara mandiri, karakter jujur dari mengerjakan evaluasi secara individu, dan karakter tanggung jawab melalui pengerjaan tugas tindak lanjut.

Penerapan model pembelajaran berbasis permainan tradisional memberikan dampak positif diantaranya berdasarkan penelitian yang dilakukan oleh Imma'u Rochmani (2016) menghasilkan permainan engklek/pande dapat meningkatkan kemampuan motorik siswa. Selain itu menurut penelitian oleh Rochmani (2016) permainan tradisional engklek/pande menuntut anak dapat berdiskusi dengan temannya dan melatih emosi anak untuk bersabar menunggu giliran tanpa mengganggu teman yang lain. Permainan ini diharapkan dapat meningkatkan karakter positif siswa sesuai pelaksanaan pendidikan karakter pada satuan pendidikan.

Dampak pembelajaran yang terbentuk tersebut sejalan dengan teori belajar sosial dari Vygotsky (dalam Trianto, 2009: 38) yang menyebutkan bahwa untuk mendapatkan pengetahuan baru, anak-anak membutuhkan interaksi penuh dengan orang lain sehingga pembelajaran menjadi efektif. Permainan pande membuat siswa aktif berinteraksi dengan guru dan teman-temannya sehingga pembelajaran menjadi efektif dan mudah diingat.

\section{SIMPULAN}

Model pembelajaran adalah suatu pola yang digunakan sebagai pedoman dalam merencanakan pembelajaran. Permainan tradisional Pande merupakan permainan yang melompati lapangan dengan tidak melanggar garis lapangan serta tidak melewati petak kunci. Model pembelajaran berbasis permainan tradisional pande yaitu model pembelajaran yang memadukan konsep permainan tradisional pande dengan materi pembelajaran. Pengintegrasian ini dilakukan dengan mengembangkan permainan sehingga sesuai dengan bagian-bagian model pembelajaran yaitu urutan langkahlangkah pembelajaran (sintak), sistem sosial, prinsip reaksi, sistem pendukung, dampak intruksional. Model ini mampu meningkatkan karakter siswa diantaranya karakter spiritual, rasa ingin tahu, komunikatif, menghargai prestasi, tanggung jawab, kerja keras, disiplin, komunikatif, menghargai prestasi, mandiri, dan jujur.

\section{DAFTAR PUSTAKA}

Andriyani, T. (2012). Permainan Tradisional Dalam Membentuk Karakter Anak Usia Dini. Jurnal Sosial Budaya Vol. 9, No. 1, hlm. 112-136.

Angela. (2013). Pengaruh Game Online Terhadap Motivasi Belajar Siswa SDN 015 Kelurahan Sidomulyo Kecamatan Samarinda Ilir. eJournal IImu Komunikasi, 2013, 1 (2): 532-544 ISSN 0000-0000, ejournal.ilkom.fisip-unmul.ac.id

Asmani, J. M. (2013). Buku Panduan Internalisasi Pendidikan Karakter Di Sekolah. Yogyakarta: Diva Press 
Dahliani; Soemarno,Ispurwono ;Setijanti, Purwanita (2015). Local Wisdom In Built Environtment In Globalization Era. International Journal of education and Research.

Kemendiknas. (2011). Panduan Penyelenggaraan Pendidikan Karakter. Badan Penelitian dan Pengembangan - Pusat Kurikulum dan Perbukuan.

Nazir, M. (2003). Metode Penelitian. Jakarta: Ghalia Indonesia

Nur, H. (2013). Membangun Karakter Anak Melalui Permainan Anak Tradisional. Jurnal Pendidikan Karakter. Tahun III, No 1, hlm. 87-94.

Qodriyah H.S. dan Wangid, M.N. (2015). Pengembangan SSP Tematik Integratif Untuk Membangun Karakter Kejujuran dan Kepedulian Siswa SD Kelas II. Jurnal Prima Edukasia, Vol. 3, No. 2, hlm. 177-189. ISSN: 2338-4743

Raharjo, M. (2012). Model Pembelajaran Inovatif. Yogyakarta: Gava Media

Rochmani. (2016). Permainan Tradisional Engklek Berpengaruh Terhadap Perkembangan Motorik Anak (Publikasi Ilmiah). Surakarta: Universitas Muhammadiyah Surakarta

Rusman. (2012). Mode-Model Pembelajaran. Jakarta: PT Raja Grafindo Persada

Suwandi, S. (2011). Model-Model Asesmen dalam Pembelajaran. Surakarta: Yuma Pustaka

Trianto. (2009). Mendesain Model Pembelajaran Inovatif-Progesif. Jakarta: Kencana Prenada Media Group. 